\title{
Mapping out the Identity of African Arts and Aesthetics
}

\author{
Joseph Situma \\ Department of Philosophy and Religious Studies \\ University of Nairobi \\ joseph.wanyama@uonbi.ac.ke
}

Fred Atoh

Department of Linguistics and African Languages

University of Nairobi, Kenya

atohfred@gmail.com

and

Juma Ndohvu

Department of Philosophy and Religious Studies

University of Nairobi, Kenya

jbndohvu@yahoo.com

DOI: http://dx.doi.org/10.4314/tp.v7i1.5

Thought and Practice: A Journal of the Philosophical Association of Kenya (PAK)

New Series, Vol.7 No.1, June 2015, pp.77-102

thoughtandpractice@gmail.com

http://ajol.info/index.php/tp/index

ISSN: 2076-7714 


\begin{abstract}
This article utilizes the hermeneutic theory of Paul Ricoeur and its concepts of text, historicity, distance, narrative and metaphor to map out the salient features of African arts and aesthetics. It also uses the Ricoeurian concept of metaphor to demarcate the boundary between art and popular art. The focus of this mapping out is literature, visual arts, music and art criticism. The identity of African literature bears imprints of various indigenous and foreign languages, and pertinent to Ricoeur, the deployment of metaphor. Thematic concerns are patently African by virtue of the historicity of the discourses that feature in the novels, poems and plays. On the other hand, art criticism in contemporary Africa manifests a lack of responsibility, and its practitioners would enhance their capacity by drawing from Ricoeur's philosophy of interpretive responsibility. Although discourse is significantly valuable in mapping out identity in the African novel, its applicability to the identity of painting, poetry and music is slightly constrained. Furthermore, Ricoeur's concept of textual autonomy is of least value in dealing with the identity features of symbolic painting and symbolic arts.
\end{abstract}

\title{
Key Words
}

African arts, Ricoeur, Criticism and Responsibility, Metaphor, Historicity 


\section{Introduction}

Identity is an important aspect of human existence, especially because its elemental features are dynamic and open to external influences. Human beings seek to understand themselves in general and in particular, and their universality and particularity require attribution. Various theorists have addressed the general issue of African identity and the identity of African arts and aesthetics more specifically, but they have not utilized Paul Ricoeur's hermeneutic theory in their endeavours. ${ }^{1}$

The relevance of Ricoeur's hermeneutic theory to the question of determining the identity of art and aesthetics is evident in many of his works. Starting with the Sassurean distinction between la parole and la langue (Ricoeur 1971, 317), he asserts that "Action is analogous to discourse because to make full sense of any action, one has to recognize that its meaning is distinguishable from its occurrence as a particular spatiotemporal event. Nevertheless, every genuine action is meaningful only because it is some specific person's doing at some particular moment." The acknowledgement of the significance of historicity in art and aesthetics is echoed in the assertion that in discourse the question "Who is speaking?" is as vital as "Who is acting?" (Regan 1996). In addition, "Whereas language lacks a subject - in the sense that the question "Who is speaking?" does not apply at this level - discourse refers back to its speaker by means of a complex set of indicators such as personal pronouns" (Ricoeur 1971, 317). These distinctions are pertinent to the inquiry into the identity of African arts and aesthetics.

Ricoeur (2000) expounds the concept of responsibility in a manner that is relevant to determining the status of the arts and practice of art criticism in Africa. He asserts that "Neither in literary criticism nor in the social sciences is there such a last word" (Reagan 1998, 77). Moreover, his discourse on metaphor is valuable because it is a

\footnotetext{
${ }^{1}$ For examples, Joseph Situma, 1998. "Paradigmatic Constraints and Africa's Quest for Identity". Presbey, Gail, Daniel Smith, Oriare Nyarwath and Pamela Abuya eds. Thought and Practice in African Philosophy. Occasional papers of the International Society for African Philosophy and Studies (ISAPS). Nairobi: Konrad Adenauer Foundation, pp.97106; D.A. Masolo, 1994. African Philosophy In search of Identity. Bloomington: Indiana University Press; V.Y.Mudimbe, 1998. The Invention of Africa: Gnosis, Philosophy, and the Order of Knowledge. Bloomington: Indiana University Press.
} 
synthesis of the conceptions of Aristotle (1941), Black (1962) and Beardsley (1958), and it links the concept to mimesis, which is a key element of art. It is true that "the metaphor is the rhetorical process by which discourse unleashes the power that certain fictions have to re-describe reality" (Ricoeur 1977, 7). In the light of the fact that African arts and aesthetics affirm and reflect the identity of Africans, re-description is the hallmark of the enterprise of accounting for them. Equally important is Ricoeur's discourse on narrative, mimesis and symbolism.

This article uses Paul Ricoeur's hermeneutic theory to pinpoint some salient features of African arts and aesthetics. Its scope is Africa as a cultural rather than a geographical concept (Jahn 1968, 19). ${ }^{2} \mathrm{Jahn}$ is correct in observing that African culture, music and architecture pertain to aspects which emanated from "black Africa"; and without racial connotations to the concept "black Africa", we share the view of Appiah $(1992,180)$ that identity is a purposive-construct.

In the first main part of this article, we examine Yoruba arts and aesthetics using Ricoeur's concepts and theory. In the second, we broadly look at the identity of African arts and aesthetics in the transition from the traditional to the contemporary era. In the third part we narrow down to an examination of narrative and identity. The forth part deals with the identity of African music, while the final part examines artcriticism, using the concept of responsibility.

\section{Yoruba Arts and Aesthetics}

In studies of the arts of various African peoples, literature on Yoruba arts is abundant and easily accessible. This is why this study begins by using Ricoeur's theoretical resources on Yoruba arts, and, by extension, their aesthetics.

Arts and aesthetics reflect a people's traditions, values, practices, pervasive realities and external relationships. In the traditional African set up, art is intricately bound up

\footnotetext{
${ }^{2}$ There are contrary positions on this matter, e.g. Cheikh Diop, 1974. The African Origin of Civilization: Myth or Reality? Cook, Mercer ed. and trans. Chicago: Lawrence Hill Book, and Oluwasheyi Kehinde. 2011. "Dissonance and Chromatic Inflections in Traditional African Music”. British Journal of Arts and Social Sciences, vol.3 No.1, pp.99-109. www.bjournal.co.uk/paper/bjass 3 1/bjass $03 \quad 01$ 09.pdf
} 
with religion and culture. Thus Somjee $(1992,49)$ observes that “... art objects are not mediators of aesthetics but of ritual processes and institutional law that define and maintain relationships of the sexes, age-groups, clans, and with neighbouring ethnic groups." The boundary between art, social practice and religious performance is subtle, but real (see Jahn 1968, 57-58). To illustrate this fact, one only has to witness the performance of the following Ifa divination verse:

The day Epe was created

Was the day Ase became law

Likewise, Ohun was born

The day Epe was invoked

Ase is proclaimed

Epe is called

But they both still need Ohun (Abiodun 1994, 73).

This verse cannot be properly comprehended without acknowledging the Yoruba religious beliefs and metaphysics. What do Epe, Ase and Ohun mean? Are they simply names of things or places? Abiodun $(1994,73)$ enlightens us when he asserts that without Ohun ("voice", "the verbalization or performance of the word"), neither Epe ("curse", that is, "malevolent use of ase [life-force]") nor Ase can act to fulfill its mission. Throughout his account, Abiodun affirms the intricate relationship between visual arts, music, dance, culture and religion. In this affirmation, the historicity of the verse challenges us to seek deeper understanding of the context of art works. Abiodun's account of the metaphysical, cultural and religious aspects of Yoruba thought is of heuristic value in understanding the assertions of Belton (2014) concerning the Ibeji twin statues (Yoruba), Sowo Wui Helmet (Mende of Sierra Leone) and Aron Etoma (Temne of Sierra Leone):

... four precise qualities that describe sculpture and indicate what is good and bad [are]: resemblance to a human being, luminosity, selfcomposure, and youthfulness. First, the quality of resemblance to a human being is one of the elements used by African artists to praise a carved figure. This element is used because African artists seldom portray particular people, actual animals, or the actual form of invisible spirits in their sculptures. Rather sculptures were intended to be likenesses of their living subject (sic.). Sculptures are not portraits of individuals, but they are supposed to look as if they might be. The second quality is luminosity, or the play of light and shadow over the sculptures. Another quality is self-composure, a straight and upright posture and symmetrical arrangement of the part (sic.) of the sculpture. 
This does not exclude asymmetry, but it does restrict it to fairly minor details. Finally, youthfulness is also important, the representation of the subject in the prime of life (Belton 1998).

The assertions of Belton concur with the view that "Most African art is representative, not representational. Very little African sculpture is intended to recreate the features of a human being, either living or dead.... The invented spirits these figures and masks embody are supernatural, unseen, incomprehensible, so that concrete forms that are carved to have them must also be invented" (Roy n.d.). Karl et. al. (2012) account for the representative features, such as the prominence of the head in Yoruba statues, in terms of the ontological significance of the head in human life and in providing identity.

Abiodun points out that in Yoruba language, the concept asa subsumes both style and tradition, and that in Yoruba artistic discourse, as a refers to style or the result of a creative and intelligent combination of style from a wide range of available options within the culture (Abiodun 1994). Again, this view brings out the use of medium within the margins of tradition and the extra-ordinary usage of medium which features in the works of African art. It justifies our mission of mapping out the identity of art and aesthetics. Moreover, it is in line with Jahn's assertion that in the composition of the oriki (Yoruba word meaning "poetry"), drummers invent the poem, which "... is made up ... of separate 'praise names' ... aphorisms alluding to events, stories and myths that are the common possession of the neighbourhood or the group, and which only need to be hinted at ..." (Jahn 1968, 74).

The Yoruba concept of beauty is easier to comprehend in the Yoruba notions of elegance, charm, grace, and harmony. Abiodun concluded that the Yoruba conceive character to be a necessary condition for beauty; ${ }^{3}$ and "When a thing expresses the qualities attributed to it in the oriki(poetry), it has fulfilled the most important prerequisite of ewa (beauty)" (Abiodun 1994, 23). Therefore, "without the ase, an attractive artifact would fail to make an appreciable religio-aesthetic impact (Abiodun 1994, 74). Furthermore, the significance of ase is argued to be the individualizing

\footnotetext{
${ }^{3}$ M. Matizo (2013)_has put forward a similar view of beauty in "Vimbai's 'African Social Concept of Beauty: Its Relevancy to Literary criticism"”. www.leena.co.jp
} 
force which the artist must grasp using his/her inner eye. Abiodun points out that among the Yoruba, a good poem expresses accurately and elegantly the state of a thing in its healthy, luxuriant, youthful and beautiful condition, or the state of another or the same thing in diminished, withered, and ugly condition.

How then do we account for the 'fact' that traditional African sculpture largely feature portraits of subjects in the latter state? We conjecture that this feature of sculptural art is partly due to the strong artist-patron relationship and the nature of painting and sculpture. Who would flaunt a portrait or sculpture of any being in diminished, withered, and ugly condition? In any case, granted that African art is "a complex process in which society articulates and communicates its consciousness of its origins, its past and its present predicament" (Hassan 1996, 47), it is inconceivable for society's consciousness to dwell on the negative. If art is to be society's consciousness, it must be a product of erudition, reflection, and a controlled vive of creativity. The responsibility of defining social predicament is on the shoulders of the sages, who have to do more than describe a society's origins, past and present (Oruka 1991; Presbey 1997; Kresse 2007).

However, the concept of metaphor enables us to distinguish between artists and imitators in an illuminating manner. In this regard, Bade Ajuwon writes:

Although most Nigerians knew and could recount parts of their genealogy and local history, only a few oral artists had the skill and stamina required to chant the lengthy oral literature. The oral artists, freelancers or guild-associates, enjoyed reverence as "keepers of the people's ancient wisdoms and beliefs." .... Oral artists frequently entertained their audiences dramatically, providing relaxation and teaching moral lessons (Ajuwon cited in Gardner 1990).

Gardner goes on to quote Ajuwon thus:

$" \ldots$ as a means of relaxation, farmers gather their children and sit under the moon for tale-telling. .... The telling of stories is used by narrators to instruct the young and teach them to respect the dictates of their custom: as a result, a large body of moral instruction, of societal values and norms are preserved for posterity by the Yoruba" (Ajuwon cited in Gardner 1990).

The Ricoeurian conception of metaphor as the stamp of creativity is equally useful in distinguishing imitation and original composition in other arts. In any case, imitation 
is a universal norm. ${ }^{4}$ The aesthetic values of imitations echo specific original works in figures of speech, alliterations, rhythms, melodies, color combinations, and curvatures. In this respect, there are good and bad imitations.

\section{Identity of African Art and Aesthetics in the Transition from the Traditional to the Contemporary Era}

Historicity in discourse is evident in Ajuwon's account of the transition from African oral literature to written literature, and in his examination of the contacts between the Yoruba, Arab and Western missionaries (Ajuwon cited in Gardner 1990). According to his account, the contacts formed the basis of some converts' literary outputs, but the outputs generally relied "upon their ancestral folktales in creative writing." For example, Faguna wrote pieces that "show an extensive use of proverbs, riddles, traditional jokes and other lore central to Yoruba belief" (Ajuwon cited in Gardner 1990), and therefore the works demand contextual sensitivity for full understanding.

While the novel and poem genres of Yoruba, Hausa, and Igbo artists in the 1930s are generally weaved from cultural materials, they carry various tones and express authors' positions vis-à-vis foreign religions and cultures. Ajuwon gives the example of the novel, Omenuka by Pita Mwana that uses fantasy to express anti-missionary viewpoints (Ajuwon cited in Gardner 1990). On the other hand, Cheikh Hamidou Kane in L'Aventure ambigue(1961) presents a narrative that accepts the passing away of the traditional African way of life and religion, and grapples with the challenges of accepting Islam and modernity. Even when the poems and songs do not maintain a consistent connection with the Arabic worldview, as evident in the Swahili songs of gungu and mavugo but instead "come from folklore and are scarcely arabized" (Jahn 1968, 80), historicity is evident. Traditional and contemporary aspects also arise in the works of Shaban Robert, who "expanded and modernized the vocabulary, and both in prose and verse created stylistic models adapted to modern times, which will be important for future Swahili poetry” (Jahn 1968, 80).

\footnotetext{
${ }^{4}$ Imitation is an implicit norm because human beings learn through it: children sculpt bulls, human figurines, houses, and scroll drawings of these and many other things.
} 
Ajuwon argues that in Nigerian literature, the shift from fantasy to realism resulted from the founding of the University College of Ibadan in 1948, the return to Nigeria of Western educated scholars, and the subsequent challenge for "the kind of story ... that dealt with the kind of things we could see with our eyes in Nigeria today" (Ajuwon cited in Gardner 1990). The shift in perspective, thematic range and style is evident in Chinua Achebe's Things Fall Apart. Of significance is Kofi Awonoor's observation that "[Igbo] proverbs are intricately woven into the fabric of his [Achebe's] style, completely absorbed to the extent that they constitute one of the most significant features of his totally African-derived English style" (Awonoor cited in Gardner 1990). Similarly, Ajuwon characterizes Soyinka's poetry and drama as echoing the traditional style of ritual chants, dwelling upon images of ancestral generations and the souls of the ancients (Ajuwon cited in Gardner 1990).

The writings of Chinua Achebe and Wole Soyinka demonstrate the significance of metaphor in art in the paradox of a slave using the master's language without adhering to the rules of grammar, syntax, phonology and semantics. ${ }^{5}$ Defiance of the rules of language, whether foreign or indigenous, is the mark of inventiveness which only great literary artists achieve. Achebe aptly expresses the motive behind the unorthodox uses of foreign languages when he asserts:

In one sense then [there is] a traveling away from its [African identity's] old self towards a cosmopolitan, modern identity while in another sense [there is] a journeying back to regain a threatened past and selfhood. To comprehend the dimensions of this gigantic paradox and coax from it such unparalleled inventiveness requires ... the archaic energy, the perspective and temperament of creation myths and symbolism (cited in Jeyifo 2004, 1).

Furthermore, in the creative usage of foreign languages in the immediate aftermath of colonialism, the aspect of historicity is also at play. The concept of historicity is useful in appraising the challenges of selecting values, norms and beliefs from the Western, Islamic and African heritages. In view of the work of Austin (1965), the

\footnotetext{
${ }^{5}$ Penelope Gilliat, writing about Wole Soyinka on the eve of the premiership of The Road, observed that "Every decade or so, it seems to fall on a non-English dramatist to belt new energy into the English tongue ... Wole Soyinka has done for our napping language what brigand dramatists from Ireland have done for centuries: booted it awake, rifled its pockets and scattered the loot into the middle of next week" (cited in Jeyifo, Biodun, 2004, Wole Soyinka: Politics, Poetics and Post-colonialism. Edinburgh: Cambridge University Press, p.2).
} 
problems of identity that the colonial, post-colonial and globalized world spawned are the genesis of various infelicities that are captured in the works of African artists. The narratives present historicized identities, which contest racist and colonial constructs of African identities or affirm some of those constructs. Thus Odiboh (2005) contests the view that African art is/ought to be "primitive and naive". Odiboh argues that there are many schools of art in Africa, and goes on to focus on the Abayomi Barber School, which, he reports, is opposed to Western stereotypes that link African identity/authenticity with the grotesque, weird and crudely rendered works of art. Despite the School's mandate to depict African subject matter, themes, portraits and landscapes, particularly of the Yoruba peoples, it has not earned the benevolence of an "African authentic" seal of approval by Western authors and critics.

Odiboh further asserts that "In Nigeria and in most parts of Africa (...) modern art involves a discontinuation of the forms and artistic perceptions of traditional past in favour of the ethos and idioms of Western academy" (Odiboh 2005). However, his assertion that "Distance from the past in the modern Western tradition meant breaking away from the representational" and his assertion that "Distance from the past ... meant moving away from the stylized and symbolic and towards the representational" (Odiboh 2005), are contradictory. The two assertions are also contrary to the characterization of Abiodun (1994) and Karl (2012) that African art is representative. In any case, the historicity of the works of art entails transformations such as that resultant from exposure to Western and Islamic traditions of art and aesthetics. However, the transformations build on African metaphysic, ethos, and idioms, and result in hybrid metaphysic, ethos, and idioms. Of significance in sustaining the characterization of traditional African art as representative rather than representational is the documented influence of African art on Pablo Picasso. The Abayomi School's preference of pictorial naturalism over grotesque realism does not have any aesthetic merit. ${ }^{6}$ And while "distance" from traditional metaphysic, ethos, and idioms is a reality for those in schools of art, in the rest of Africa the stylized statues of deities that bear religio-aesthetic values continue to be dominant features. In any case, a work of art

\footnotetext{
${ }^{6}$ See Weissberg, Gabriel 2010. Illusions of Reality: Naturalist Painting, Photography and Cinema, 1875-1918. Helsinki: AteneuminTaidemuseo.
} 
cannot bear the stamp of magical symbolism without the cadences of specific tradition.

In the foregoing analysis, the heuristic value of Ricoeur's thesis that human beings know themselves through interacting with other human beings, as well as the concept of the historicity of the text are affirmed. However, the assertion that “... for Ricoeur the great point about Oedipus Rex or Paradise Lost or Madame Bovary is not that they are taken back up into the culture within which they originated, but that they are also available in the timelessness of their literary autonomy ... to a human kind that possesses universal power to grasp narrative reality" (Dowling 2011), is of limited value in appreciation of statues, masquerades and verses deployed for religious and cultural purposes. The broader theory of Ricoeur, and particularly his position that a people's view of things and the practices of their lives amount to a process of selfunderstanding, and that this requires relationships with other human beings (Dauenhauer and Pellauer 2014) has enabled us to measure the distance of contemporary art from African traditional themes, styles and idioms.

\section{Narrative and Identity}

Important for us too is Ricoeur's argument for the significance of the concept of narrative, granted it is "one of the ways in which we answer the questions 'Who?' 'Who is this?' 'Who said that?' ...? 'Who are we?'” (Pellaeur and Dauenhauer 2016). In a literary narrative, a fictional individual interacts with other fictional human beings dialogically, physically, sexually, economically, etcetera. Although we identify the modes of interaction in particular terms, in reality all could and do occur simultaneously. African narratives offer mimetic portraits of the African people in pre-colonial, colonial, and postcolonial settings. Ngugi wa Thiong'o justifies the variations of the narratives in his assertion that "drama has origins in human struggles with nature and others" (Thiong'o 1994, 36). This means that realistic narratives will reflect the social setting of human struggles, complete with the appropriate indications of rituals, ceremonies, status, and values. That is why when colonial governments imposed banned social gatherings in some volatile societies, realistic deployment of oral narratives ceased. Radio and other framed presentations of religiously inspired and communally centered scripts entailed artificiality and parody, and this stand in 
contrast to the performances of the artist-sage in traditional setting. Moreover, narratives scripted to suit colonial governments' ideological interests are unabashedly hegemonic, and stand in contrast to works of art that make use of the socio-cultural resources of various African cultures, such as Wole Soyinka's Death and the King's Horseman, Achebe's Arrow of God, Armah's Two Thousand Seasons, Ngugi wa Thiong'o's The River Between, Ogot's The Land of Thunder, Okri'sThe Famished Road, and the explicit parodying of Western culture in p'Bitek's Song of Lawino.

The connection between narrative and identity is useful in appreciating works that mirror the shift from the predicaments of being a colonized people to the predicaments of the postcolonial era characterized by images of hope, black bourgeois greed, mass poverty, despair, oppression and repression. In the post-colonial era, we encounter spatiotemporal tuned projects and intentions in Achebe's Anthills of the Savanah, Armah's Why are we so Blessed, and Ngugi wa Thiong'o'sWizard of the Crow. These works carry mimetic portraits of African people undertaking their life projects in contexts of nations at infancy - clinging to the breasts of their 'mothers', prone to blunders, and without the wisdom to secure all their members. The characters in the narratives have identities that are in form of individual indebtedness to our predecessors, our obligations in the present in our various capacities, and our expectations on others in the future. Through a narrative, we are able to "construct the identity of the character, what can be called his or her narrative identity, in constructing that of the story" (Ricoeur 1992, 148). Obviously, an identity is imbedded in a genealogy that is a trace of ancestry, relations, and memory. It is against a backdrop of indebtedness to predecessors, individual and collective obligations and expectations that Francis Imbuga's Betrayal in the City, Ngugi wa Thiong'o's The Grain of Wheat, and Likiman's What Does a Man Want arise. The discourse in these and other works make sense to us because "discourse is addressed to someone"( Ricoeur 1971, 321). The mimetic forms are African insofar as they carry the nuances of Africa, and so there is the African family, love-story, leader, widow, and intellectual. And so even though widowhood, for example, is a universal phenomenon, its particularities are African because the challenges in the form of norms, taboos and values are uniquely African. 
Discourse, according to Ricoeur, is about saying something about something according to the malleable rules of language. Even so, African narratives carry dictions of specific people - the Igbo of Nigeria, the Giriama of Kenya, the Zulu of South Africa, and so forth. Moreover, discourse between various interlocutors (characters in narratives) reveals their identities - habits, social status, self-expression, intelligence, temperaments, and sociability. Although these are universal aspects of personality, specific moral communities' prescriptions and proscriptions determine their manifestations, and hence the importance of setting in narrative. Since we are able to access the motives of characters in narratives unlike in real life, we can utilize the concept of the historicity of discourse and Ricoeur's thesis that once the narrative is written, "instead of being addressed just to you, the second person, what is written is addressed to the audience that it creates itself. The vis-a-vis of the written is just whoever knows how to read" (Ricoeur 1971, 321). We are partially able to account for the universal range of addressees of the narratives of African writers and nonAfrican writers. However, even when the universal range of addressees is achieved, the existential dimensions of the text are not completely removed. Indeed, the existential dimensions surface in the process of transforming narratives into theatre scripts.

The poetry of communities will also feature culture-nuanced metaphors that have to be interpreted both at particular and universal levels. Ricoeur acknowledges this in Rules of Metaphor, where he asserts that metaphors "are untranslatable without remainder into literal language" (cited in Dauenhauer et. al. 2014). This is because metaphoric language has newness that cannot be captured in literal language; and as Ricoeur observes in concurrence with Aristotle, poetic language is the acme of metaphoric language (Ricoeur 1975, 2).

One outcome of urbanization in Kenya is the emergence of sheng' ${ }^{7}$ as an alternative language of use in literature with it sub-genres of short stories based on personal experiences and real-time reportage. Ojwang' is correct in observing that the literati circles of the sub-genre are distant from the universities and the standard versions of

\footnotetext{
${ }^{7}$ Sheng' is a mix of English, Kiswahili and various local Kenyan languages.
} 
English and Kiswahili (Ojwang' 2009, 3). In other words, there are hybrid identities and, in the realm of discourse, heterogeneous and polyphonic works of art.

\section{African Identity in Music}

In contrast to the literary realm, there have scarcely been robust contests on the identity of African music. In general, the distinctive rhythmic African music is the outcome of the diverse use of instruments in the three main categories, namely, string, wind and percussion. Artisans design and fashion fiddles, horns, flutes and percussion instruments from whatever appropriate materials that a people's environment affords, and in Africa the materials include animal horns and hides, bamboo sticks, and metallic triangles. Each instrument has its timbre, and the choice of instrument is a function of the individual's background, aptitude and the availability of instruments. ${ }^{8}$

Furthermore, African music is a communal event. Hand clapping, finger popping, vocal prompting, and foot tapping during performances are not considered offensive, but are viewed as signs of ardent approval that help to motivate the performing artist. The audience and the performing artist are joined together in the world of performance. This essentially makes the critic of the African musical art part of the cast, and therefore the Ricoeurian concept of distance has to be applied delicately. Contemporary traditional African music and drama feature themes of communal significance such as births, the onset of rain, harvest, drought and death, among others. In this regard Nketia observes:

In traditional African societies, music making is generally organized as a social event. Public performances, therefore, take place on social occasions - that is, occasions when members of a group or a community come together for the enjoyment of leisure, for recreational activities, or for the performance of a rite, ceremony, festival, or any kind of collective activity, such as building bridges, clearing paths, going on a search party, or putting out fires - activities that, in industrialized societies, might be assigned to specialized agencies (Nketia 1974, 21).

\footnotetext{
${ }^{8}$ For a deeper appreciation of these factors, see E. Edwin Gordon's "A Study of the Characteristics of the Instrument Timbre Preference Test” (1991). Front Matter: Bulletin of the Council for Research in Music Education. Illinois: University of Illinois Press.
} 
The concurrence of music performance and the collective leads us to find credence in the argument of Frith $(1996,109)$ that "the issue is not how a particular piece of music or performance reflects people, but how it produces them, how it creates and constructs an experience ..." In other words, the music bears the identity of the community and the community bears the identity of the music. The participation of the community, which can only happen through the individual, is inseparable from the music.

Among the Mande, musicians known as jalolu (Mande word for "itinerant poets") compose and perform in praise of kings, the wealthy, and friends: this music makes the people. Such is the traditional Jali Music of Mali, a good example of which is jalolu Tata Bamba Kouyate in the song Mama Batchily. Jahn $(1968,65)$ suggests that "The art of poetic improvisation within the framework of the historical style has also been preserved up to modern times. In the bars of big African towns a praise song is improvised for any prominent guest ...."

The diversity of African music is evident in Elechi Amadi's details of the instruments that are used in the oduma dance. These include the oduma (a percussion instrument that consists of twelve unequal and rather flat pieces of wood carefully smoothed), two drums (the male and female), four types of okwo (hollow tree trunks), whose tone quality depend on the capacity and depth of its hollow interior, and igele (hollow metal gong)" (Amadi 1992, 27). ${ }^{9}$ In Amadi's description, the musical performance is not a rigidly framed act, but an all-inclusive event in which dancers respond spontaneously to the soloist. The critic has to appreciate when members of the audience suddenly burst into ululation, a whistle, a jig or a gentle nod of the head; the critic has to appreciate why the artist cannot end the song his way when people still want to continue, so that he/she has to continue creating or someone from his/her audience will do so. In this respect, Barz $(2004,13)$ argues that in Africa “... music is typically not transcribed, notated or analyzed .... Music is, however, often recorded, traded, sold, practiced, performed, and discussed. It is purposefully woven into the fabric of everyday life and reflected on ...."

\footnotetext{
${ }^{9}$ This nuanced instrumentation leads to music that is distinctive, so that within a country there will be as many varieties of music as the ethno-linguistic communities in it.
} 
Moreover, while in the Western tradition musical representation is largely textual first and oral second, in the African tradition music has life and is life. Its beauty resides in its oral rendition more than in anything else. It is worth noting that the textual representation may, unfortunately, distort the colour of this beauty. This is so when the Western devices of composition and harmony are imposed on the African song. Certain nuances of the music are lost in the process of such representations and performances. Gaining access to these, often vital but covert features of meaning in African musical art, requires direct participation of the critic. Although we have not had the benefit of listening to the music of the oduma dance (Amadi 1992, 27), we conjecture that an antiphonal structure is realized in the rendition of male and female drums, and this reflects the voices of the singers. Drums produce the tom-toms that define African traditional music and, in some cases, drums dominate the appoggiaturas $^{10}$ with deep, hard beat that are matched with frenzied gyrations and grinding. Okot p'Bitek offers a relevant and enlightening insight into African music and dance:

When the drums are throbbing

And the black youths

Have raised much dust

You dance with vigour and health

You dance naughtily with pride

You dance with spirit

You compete, you insult, you provoke

You challenge all!

And the eyes of young men become red! (P'Bitek 1966, 49).

In addition to the dance, p'Bitek offers a relevant account of Acoli aesthetics in Lawino's description of the colour scheme for dance in the form of matching red hair with red ochre for the body, red string skirt, black string skirt, akuku-hairdo, and simsim oil smeared body.

\footnotetext{
${ }^{10}$ An appoggiatura is an ornamental note of long or short duration that temporarily displaces, and subsequently resolves into, a main note, usually by stepwise motion. Moses Isegawa'sThe Abyssinia Chronicles describes the wedding music in these terms. We witness a similar appoggiatura in ElechiAmadi's The Concubine, in a passage on the Oduma dance of the young and agile.
} 
Since traditional African music, such as the oduma dance, was orally passed down from generation to generation and performed by diverse musicians, the performer provided articulation and phrasing. According to Clive Brown (2008), provision of these two aspects of music depends on experience and musicality of the performer. Although the absence of written compositional details such as accents, trills, appoggiaturas and other elements entailed a difficulty in identifying musical composers, this same aspect provided greater latitude for use of individual talent, imagination and ingenuity to the performers. The fact that there is no rigid frame, coupled with the absence of pre-meditated details, goes a long way in affirming the view of Agordoh $(2005,11)$ that there is "closeness between the arts (music included) and the utilitarian in everyday life." The fusion of music and life projects itself as a subject of composition in different fora, and the artist takes advantage of it to act as the people's mouthpiece on a matter of interest to them.

The oduma dance and instrumentation, and our conjectures, affirm the Ricoeurian thesis of the historicity of the text and its existential dimensions. Just as in the case of oral narratives, where we made a pertinent distinction between the fireside narrations in the villages and the original narration, here too is a distinction between the original composer and the various performances. The "song composed in Emenike's honour...sung with unavoidable melancholy" (Amadi 1992, 28), would be rendered differently by a performer who has scant knowledge of the subject. Definitely, the subject's wife, Ihuoma, would sing the same song in a distinctly engaged manner.

The connection of the word to the emotions is evident in the fact that a funeral dance of the Acoli of Uganda, for example, taken out of context and performed on stage becomes an empty shell. Viewed in this way, the lyrics of a melody carry emotional power. A Westerner too would appreciate the significance of social-psychological aspects in music, granted the divergent comportments that different cultures prescribe for observance of birth, marriage, and funeral rites, among others. Nevertheless, in traditional African music, the aspect of chance is greater, and musicians have some freedom as to the choice of pitch and rhythm. The point of departure for the performer is memory of, and reflections on, outstanding performances of a musical piece. 
Contemporary African music is composed in the same way as contemporary Western music, with abbreviated instructions of what the performer should do. However, as already pointed out, unique historical and existential aspects feature in the performance of the music and poems of Africa, and they are to a certain degree relevant to the interpretation of text ${ }^{11}$, and this demonstrates the relative autonomy of the text. Thus, Dauenhauer et. al. assert:

Like discourse, actions are 'open worlds' whose meaning, which outlives their initial performance, is not fully determined by their performers and their immediate audiences. As the study of history shows, there are multiple ways that a past action remains open to interpretation. One can reasonably investigate what it meant to those who knew about it when it occurred. But one can also ask how those who came later understood and assessed it, or even what it might mean today or in a possible future (Dauenhauer et. al. 2014).

Although contemporary African music features as diverse instruments as the diverse African ethno-linguistic communities in the continent and beyond, there are differences from one region to another that are the outcome of slavery and other exotic influences. In West Africa, instrumentation bears traces of trans-Atlantic interaction, as evident in the nature of High Life music in Ghana and Nigeria, in which the "arpeggiated highlife guitar part is modeled after an Afro-Cuban guajeo". ${ }^{12}$ The Senegalese band Orchestra Baobab plays in a basic salsa style with congas and timbales, with addition of Wolof and Mandinka instruments and lyrics. It is observed that, "From [the] $21^{\text {st }}$ Century, [there has been] a new type of sound combining influences from Congolese rumba, hip hop, and dancehall”. ${ }^{13}$ Similarly, the High Life music of E.T. Mensah incorporates local melodies and rhythms into the

\footnotetext{
${ }^{11}$ Mweseli asserts as much in her analysis of Okot p'Bitek's work when she comments that the metaphor of "the pumpkin in the old household" is "rarely obscure and unclear to African readers" (Mweseli 2004).

${ }^{12}$ This is a direct outcome of slave trade, and another illustration of the value of historical tracers.

${ }^{13}$ Wikipedia makes this observation based on an article in The Guardian, August 4 2014, under the headline "How Nigeria's Afrobeats are defining the Sound of Africa". Two songs are specifically cited in this respect, namely, "African Queen" by 2face Idibia (2004) and "No One Like You" by P-Square (2007).
} 
Western music, and replaces European ballroom-style music with local language melodies. $^{14}$

Contemporary music in central Africa features the use of the guitar, French lyrics, and local sensibilities. In the case of Franco Makiadi of the famous TPOK Jazz, the music features full orchestra, a lead vocal bass, cadenzas, antiphonal arrangements and extensive appoggiaturas. Around Lake Victoria in Kenya, the eight-string lyre (nyatiti) was the key instrument that produced syncopated melodies. Today, instead of the nyatiti, contemporary benga musicians use the electric bass guitar to effect the syncopation. Collela Mazee's "Mary Nyar Gem (Mary Daughter of Gem)" and "Pamisa" feature the sounds of lead vocals, three electric guitars, drums, percussion, and backing vocals. Of the two tracks, "Pamisa" has fast rhythm, and the lead vocals are accompanied by dominating high-pitched guitar, backed by vocals and heavy percussions.

Even though there are limited identity contestations in respect of music, the sociocultural and historical genesis of music is reflected in the rhythms, melodies and symbolism. In a particular genre, barring some interventions, the degree of symbolism is directly correlated to the background of the composer, which means that all factors held constant, the composition of the Western socialized composer will feature less use of symbolism and lower sophistication in the usage. As we already noted, the existential situation from which a text emerges is of significance to accessing its meaning.

In Africa, music criticism is barely in existence. Perhaps this is because unlike the literary text, about which anybody can comment on specific characters and on matters of phrasing, music appreciation is stuck between the dimension of reason and that of intuition. Than any other art, music is so emotive that appreciation could be as brief as "It is great!" Only experts are in a position to offer a systematic appreciation of music in terms of elements of melody, harmony, counterpoint, form, and so forth. Here Ricoeur's concept of distance is useful in appreciating the musician, the listener and 
the critic. Pertinent to our concern about the identity of African aesthetics, De Ganay $(1942,239)$ reported that the sound of a xylophone "singing in several voices excited a feeling of joy, of contentment, which most often is further enhanced by the pleasure of watching a virtuoso skillfully wielding his beaters." He went on to observe:

... in a cycle of excitement the listener's hair alternately rose on end and fell again, but when the pleasure was most intense contemplation ceased and he arises, for the desire to dance has become irresistible. The musician on the other hand, must not abandon himself to the contentment engendered by the music. The pleasure which he experiences will only give more ardour and skill to his playing if he knows how to stay entirely master of his sensations ... (De Ganay 1942, 239).

This description captures a subtle experiential event that significantly defines how listeners and performers relate to music in Africa. It is an acknowledgement of a physical dimension to aesthetics where body is not divorced from mind as is traditionally the case in Western aesthetic criticism. On the contrary, music reaches out to and affects the listener physically. In the $4^{\text {th }}$ century, St. Augustine, a native of North Africa, was troubled by this sensuousness and recorded in his Confessions thus:

It is no good that the mind should be enervated by this bodily pleasure and whenever it happens that I am more moved by this singing, than by the thing sung, I admit I have grievously sinned (Augustine 1943, 194).

Augustine's concern has featured prominently in the history of gospel music. Some of the Christian denominations have sought to minimize the stylized manner in which church music is presented, because this has the potential of effecting bodily pleasure that overshadows the spiritual message of the music. Generally, in the realm of music the act of presentation is of as much significance as the written composition, because it is in the former forms that music is widely accessed and appreciated. Thus, for example, much of the African-American music was the outcome of improvisation and was initially sang, and only later recorded.

The distinction between singing and what is sung leads us back to Ricoeur's concept of responsibility. Music is supposed to thrill and invigorate, but it can also have social significance, evident in Eric Wainaina's song, "Nchi ya Kitu Kidogo" (Kiswahili for "The Country of Bribery") and Wole Soyinka and Tunji Oyelana's "Unlimited Liability Company". The latter, in Pidgin English, is rendered as follows: 
You tief one kobo dey put you for prison

You tief one million, na patriotism

Dem go give you chieftaincy and national honour

You tief even bigger, dem go say narumour

Monkey dey work, baboon dey chop

Sweet pounded yam-someday 'e go stop!

(You steal one Kobo ${ }^{15}$ they put you in prison

You steal one million [Naira], and [this is regarded as] patriotism:

They give you chieftaincy and national honor

You steal even bigger, they say its rumour

Monkeys work, baboons eat

Sweet pounded yam - some day you will stop) (Soyinka and Oyelana 1983).

Thematic issues of African music are either substantively unique or are presented in linguistic forms that arise from the popular culture of the musician. Nevertheless, a substantial part of African music deals with universal themes of loss, desire, aspiration, adoration, and bereavement, all of which are universal themes.

\section{Art Criticism and Responsibility}

In this penultimate section, we use Ricoeur's concept of responsibility to look at art criticism in traditional and contemporary Africa. According to Abiodun, among the Yoruba, "Not everyone can be an art critic or amewa(expert on beauty) (Abiodun 1994). Rather, an art critic must "demonstrate these qualities: ifarable (calmness and control), iluti (teachableness and comprehensibility), imoju-mora (sensitivity), and tito (enduring, lasting, and steadfastness)(Abiodun 1994). In a later article, Abiodun asserts that: "Iluti (literally "good hearing") idiomatically refers to qualities such as obedience, teachableness, understanding and, above all, the ability to communicate." In addition to these qualities, Abiodun $(1994,73)$ includes insightfulness, design consciousness and originality, all of which require training.

\footnotetext{
${ }^{15}$ A Kobo is a very small denomination of the Nigerian currency: it is to the Naira what a Cent is to a Shilling or a Dollar.
} 
In a study of criticism among the Shona, Matizo explores "the social concept of beauty", and cites Gelfand's assertion that the virtues of literary criticism among the Shona include truthfulness, humility, love, sympathy, self-discipline, pity, patience, courage and hardwork (Matizo 2013, 63). Since contemporary literary training does not include moral curricula, it is improbable that the virtues are a prerequisite for the Western educated critics. Moreover, while the prerequisites that Abiodun attributes to the Yoruba essentially hinge on intelligence, Matizo's account of the Shona perspective lays emphasis on virtues.

Unlike traditional African criticism, contemporary criticism deals with written and therefore fixed texts, and the practitioners use universal resources in forms of theories and concepts. Moreover, art critics operate from various distances and therefore interpret the text with less bias. Still, "A specific kind of one-sidedness is implied in the act of reading. This one-sidedness confirms the guess character of interpretation" (Ricoeur 1971, 330). This means that apart from lacking moral training, contemporary critics utilize theories which have inherent biases. Abiodun (1994) warns about the danger of analyzing African art, pointing out that the compartmentalization of the arts into aspects such as painting, sculpture and literature that is the hallmark of Western scholarship is an impediment to understanding traditional African art. Nevertheless, the hermeneutics of Ricoeur concur with Abiodun's in the assertion that:

... what the dialogue ultimately refers to is the situation common to the interlocutors. This situation in a way surrounds the dialogue, and its landmarks can all be shown by a gesture, or by pointing a finger, or designated in an ostensive manner by the discourse itself through the oblique reference of those other indicators which are demonstratives, the adverbs of time and place, and the tense of the verb (Ricoeur 1971, 320).

What this citation means is that the critic in a traditional African community knows much more than what a written text asserts. In our view, this extra knowledge enables the traditional critic to be sensitive and more insightful than the contemporary critic. Liberation of discourse, when rendered in written forms, is a double-edged sword: while it facilitates universal access to the work of art, it diminishes the immediacy of responsibility. Unlike philosophical and scientific discourse that are universally accessible, drama, dance, and to some extent music are not ideationally accessible, and aesthetic values and judgments vary across traditions, generations and cultures. 
In any case, the concept of responsibility can anchor the practice of literary criticism in a framework of sympathetic handling of texts in the pre-and post-publishing stages. This would be a manifestation of hospitality, sympathy and responsibility on the part of art critics. Oguibe writes:

While art may grow and flourish under trying circumstances, albeit in an almost determinable direction, the criticism of art suffers with the general moral and intellectual configurations of a society in distress .... In cultures where the worth of rigor is constantly under pressure from the prevalence of moral compromise and the imminence of decadence, and the pursuit of excellence gives way to exigency and laxity, criticism inevitably suffers. A culture of criticism must inextricably go with a social atmosphere of tolerance, curiosity, availability to scrutiny, and the desire for progress (Oguibe 1996, 1).

These assertions characterize the state of art criticism in Africa, and challenge its practitioners to resist "the reification of a founding historical or mythical even into a fixed dogma ... by showing how each even may be told in different ways by different generations and different narrators" (Kearney 2007, 155). Apart from being armed with universal resources, practitioners of art criticism ought to embrace interpretive responsibility, which entails being aware that "In making an interpretation we are ... making a commitment. At the very least we are committing ourselves to the truth of what we say and the validity of the reasons that have led us to that conclusion" (Standen 2013, 225). This is because lack of responsibility promotes a future in which few new works of art are visible and a sense of stagnation prevails, and this is contrary to "the ethic of hospitality" (Kearney 2007, 155). These ethical considerations would eliminate patronage relationships with publishers and bias in art criticism, and provide an antidote to mediocrity. Furthermore, interpretative responsibility would ensure meticulous handling of texts (Reagan 1998, 16) and transparent parameters in assessments of works of art.

\section{Conclusion}

Even though Abiodun (1994) cautions against relying on Western theories in dealing with African art, granted the absence of moral training in contemporary curricula, it would be helpful for art critics to explore existing discourses on interpretive 
responsibility because this would enable them to take "responsibility in imagination and in sympathy for the story of Other, through the life narratives which concern Other" (Kearney 2007, 155). In any case, responsibility is inescapable given Ricoeur's assertion of "a primacy for a fundamental ethical intention that consists in aiming at the good life with and for others in just institutions" (cited in Dauenhauer 2014, 354).

African arts and aesthetics have gone through various transformations which point to exotic influences. The most outstanding transformations are in the realm of literature and music, where many African writers and musicians have appropriated and domesticated foreign languages and art forms. The fact that African visual arts influenced Pablo Picasso to transit into cubism attests to the greatness of the African tradition. Wole Soyinka was probably awarded the Nobel Prize for literature because his prose, poetry and plays are veritable gems of metaphoric language and textual autonomy.

However, the concept of textual autonomy is extremely inapplicable in dealing with symbolic painting and, generally, symbolic arts. ${ }^{16}$ For example, how would Ricoeur the autonomy theorist make sense of the creases that adorn the Sowo-Wui mask? According to Belton, "The creases ... function as a metaphor for wealth and status, and by extension beauty and sexual allure" (Belton 2014). Moreover, while Ricoeur's distinction between discourse and language is vital in dealing with art and popular culture, and also in dealing with the identity of the African novel, its applicability to the appreciation of the identity of painting, poetry and music is constrained.

\footnotetext{
${ }^{16}$ See Val-Jean Belton's “African Art and Aesthetics” (Belton 2014), in which the intuitive and symbolic nature of African art is asserted. Also in concurrence with our reservations on the thesis of textual autonomy is the post-structuralist position that to access aspects of sense, meaning, value, purpose and the inner aspects of life we have to do more than analyze the text.
} 


\section{References}

Abiodun, Rowland. 1994. "Understanding Yoruba Art and Aesthetics: The Concept of Ase". African Arts, Vol.xxvii No.3.

Agordoh, Alexander. 2005. African Music: Traditional and Contemporary. New York: Nova Science Publishers, Inc.

Amadi, Elechi. 1992. The Concubine. Nairobi: East African Educational Publishers Ltd.

Appiah, Kwame Anthony. 1992. In My Father's House: Africa in the Philosophy of Culture. New York: Oxford University Press.

Aristotle. 1943. "Poetics". Mckeon, R. ed. The Basic Works of Aristotle. Ingram, Bywater trans. New York: Random House.

Augustine. 1942. Confessions of St Augustine. Sheed, F.J. trans. London: Sheed and Ward.

Barz, Gregory. 2004. Music in East Africa: Experiencing Music, Expressing Culture. Oxford: Oxford University Press.

Beardsley, Monroe. 1981. Aesthetics: Problems in the Philosophy of Criticism, 2nd Ed. Indianapolis: Hackett Publishing Co.

Belton, Val-Jean. 2014. "African Art and Aesthetics". www.yale.edu/ynht/curriculum/units/1998/3/98.03.02.x.html

Black, Max. 1962. Models and Metaphors. Ithaca: Cornell University Press.

Bleicher, Josef. 1988. Contemporary Hermeneutics: Hermeneutic as Method, Philosophy, and Critique. London: Routledge.

Brown, Clive. 2008. Classical and Romantic Performing Practice: 1750-1900. Oxford Scholarship Online. http://www.oxfordscholarship.com/view/10.1093/acprof:oso/9780198161653

Dauenhauer, Bernard and David Pellauer. 2014. "Paul Ricoeur". The Stanford Encyclopedia of Philosophy. Zalta, Edward. N. ed. http://plato.stanford.ed/archives/sum2014/entries/ricoeur

Diop, Cheikh. 1974. The African Origin of Civilization: Myth or Reality? Cook, Mercer ed. and trans. Chicago: Lawrence Hill Book.

Dowling, William. 2011. Time and Narrative: Introduction to Temps Etrecit. Notre Dame: University of Notre Dame.

Gardner, Laura. 1990. "Nigerian Literature: Oral and Written Traditions". Africa Post-colonial Literature in English. www.postcolonialweb.org/nigeria/orality.html

Gordon, E. Edwin. 1991. "A Study of the Characteristics of the Instrument Timbre Preference Test". Front Matter: Bulletin of the Council for Research in Music Education. Illinois: University of Illinois Press. http://www.jstor.org/stable/40318457

Hassan, Salah. 1996. "The Modernist Experience in African Art: Towards Critical Understanding". Altbach, Philip and Salah Hassan eds. The Muse of Modernity: Essays on Culture and Development. Trenton, NJ: Africa World Press, pp.36-61.

Ilo, Isaiah. 2006. "Language in Modern African Drama". Comparative Literature and Culture, Vol.8 No.4. http://dx.doi.org/10.7771/1481-4374.1320 
Jahn, Janheinz. 1968. Neo-African Literature: A History of Black Writing. New York: Grove Press, Inc.

Jeyifo, Biodun. 2004. Wole Soyinka: Politics, Poetics, and Postcolonialism. New York: Cambridge University Press.

Kehinde, Oluwasheyi. 2011. "Dissonance and Chromatic Inflections in Traditional African Music". British Journal of Arts and Social Sciences, vol.3 No.1, pp.99-109. www.bjournal.co.uk/paper/bjass 3 1/bjass $0301 \quad 09 . p d f$

Matizo, M. 2013. "Vimbai's 'African Social Concept of Beauty: Its Relevancy to Literary criticism"”. www.leena.co.jp

Mweseli, Monica. 2004. A Study of Okot p'Bitek's Poetry. Nairobi: Africa wide Network.

Odiboh, Freeborn. 2005. "The Crisis of Appropriating Identity for African Art and Artists: The Abayomi Barber School Responsorial Paradigm". http://hdl.net/2027/spo.4761 563.0002.103

Oguibe, Olu. 1997. "Art Criticism in Africa: Thoughts towards a New Century". Deepwell, Katy ed. African Art and Criticism: Nigeria, Zimbabwe and South Africa. London: Saffron Books, pp.97-107.

Ojwang', Dan. 2009. "Special Issue: Eastern African Literary and Intellectual Landscape". Postcolonial Text, Vol.5 No.3.

P'Bitek, Okot. 1966. The Song of Lawino (A Lament). Nairobi: East African Educational Publishers Ltd.

Ricoeur, Paul. $\quad$ 1971. "The Model of the Text: Meaningful Action Considered as a Text”. Social Research, Vol.38, pp.529-555.

--. 1992. Oneself As Another. Blamey, Kathleen trans. Chicago: University of Chicago Press.

Reagan, Charles. 1998. Paul Ricoeur: His Life and Work. Chicago: University of Chicago Press.

Roy, Christopher. N.d. "The Art of Burkina Faso". https://africa.uima.uiowa.edu/topic-essays/shows/37?start=46

Soyinka, Wole and Tunji Oyelana. 1983. "Unlimited Liability Company" ( sang by the two artistes and the band named "His Benders").

Standen, David. 2013. "Textual Hermeneutics, Interpretive Responsibility and Objectification and Interpretation of Action: Paul Ricoeur and 'The Model of the Text"". unpublished Ph.D. Thesis at the University of East Anglia.

Weissberg, Gabriel. 2010. Illusions of Reality: Naturalist Painting, Photography and Cinema, 1875-1918. Helsinki: AteneuminTaidemuseo. 